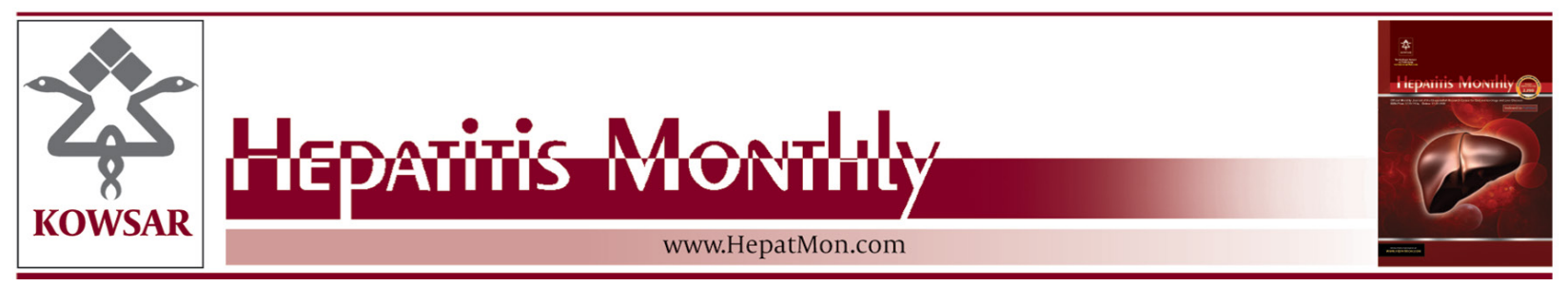

\title{
Prevalence of Hepatitis D in the Eastern Mediterranean Region: Systematic Review and Meta Analysis
}

\author{
Neda Amini ${ }^{1}$, Seyed Moayed Alavian ${ }^{2, *}$, Ali Kabir ${ }^{3,4}$, Seyed Hossein Aalaei-Andabili ${ }^{2}$, Seyed \\ Yasser Saiedi Hosseini ${ }^{2}$, Mario Rizzetto ${ }^{5}$ \\ ${ }^{1}$ Tehran University of Medical Sciences, Students' Scientific Research Centre, Tehran, IR Iran \\ ${ }^{2}$ Baqiyatallah Research Center for Gastroenterology and Liver Diseases, Baqiyatallah University of Medical Sciences, Tehran, IR Iran \\ ${ }^{3}$ Department of Epidemiology, School of Public Health, Shahid Beheshti University of Medical Sciences, Tehran, IR Iran \\ ${ }^{4}$ Center for Educational Research in Medical Sciences, Tehran University of Medical Sciences, Tehran, IR Iran \\ ${ }^{5}$ Division of Gastroenterology, Molinette - University of Turin, Corso Bramante, Turin, Italy \\ * Corresponding author: Seyed Moayed Alavian, Baqiyatallah Research Center for Gastroenterology and Liver Diseases, Baqiyatallah University of Medical \\ Sciences, Tehran, IR Iran. Tel.: +98-2188067114, Fax: +98-2188067114, E-mail: editor@hepatmon.com.
}

\begin{abstract}
A B $=$ S T R A C T
Background: Hepatitis D Virus (HDV) causes the most threatening form of chronic viral hepatitis. To date, there is no overall estimation of HDV prevalence in the Eastern Mediterranean Region Office of WHO (EMRO) countries.

objectives: To provide a clear estimation of HDV prevalence in the aforementioned region.

Patients and Methods: In the current systematic review, databases such as PubMed, Embase, Web of sciences and Google scholar were searched Until December 2010. The summary estimate of HDV prevalence in the EMRO region was calculated as an average of the pooled infection prevalence of each country weighted by the ratio of the country's HBV population to the study's sample size in the survey data analysis.

Results: We included 62 eligible studies. The weighted mean of HDV prevalence in the EMRO region was 14.74\% (95\% CI: 14.73 - 14.77), 27.8\% (95\% CI: 27.78 - 27.82), 36.57\% (95\% CI:36.55 - 36.59) and 16.44\%. (95\% CI:16.42 - 16.46) in asymptomatic HBsAg positive carriers, chronic hepatitis patients, cirrhosis/ hepatocellular carcinoma, and high risk group, respectively. Among the asymptomatic HBsAg positive group, HDV prevalence was increased by years in older patients in Saudi Arabia but its prevalence was decreased in Iran. No specific pattern was seen according to chronological analysis during years among the EMRO countries.

Conclusions: HDV infection is endemic in the EMRO countries and it is more common among patients with severe forms of hepatitis. Due to the high HDV infection rates in the EMRO countries, we recommend blood screening for HDV infection in this region.
\end{abstract}

Keywords: Epidemiology; EMRO; Hepatitis D; Meta-Analysis; Prevalence

Copyright () 2013, Kowsar Corp.; Published by Kowsar Corp.

Article type: Research Article; Received: 15 Aug 2012, Revised: 01 Sep 2012, Accepted: 22 Sep 2012; DOI: 10.5812/hepatmon.8210

Implication for health policy/practice/research/medical education:

Since there are few epidemiological studies in the Eastern Mediterranean Region Office of WHO (EMRO) countries and there is not any overall estimation of hepatitis D infection prevalence in this region, we designed a literature review.This paper can be used by epidemiologist, gastroenterologist who are interested to Epidemiology of hepatitis.

-Please cite this paper as:

Amini N, Alavian SM, Kabir A, Aalaei-Andabili SH, Saiedi Hosseini SY, Rizzetto M. Prevalence of Hepatitis D in Eastern Mediterranean Region: Systematic Review and Meta Analysis. Hepat Mon. 2013;13(1):e8210. DOI:10.5812/hepatmon.8210

Copyright (C) 2013, Kowsar Corp.; Published by Kowsar Corp.

This is an Open Access article distributed under the terms of the Creative Commons Attribution License (http://creativecommons.org/licenses/by/3.0), which permits unrestricted use, distribution, and reproduction in any medium, provided the original work is properly cited. 


\section{Background}

The hepatitis D virus (HDV) was detected by Rizzetto among patients with a severe form of HBV infection in the year of 1977 (1). HDV is a deformed and incomplete delta agent RNA virus which is dependent on HBsAg for transmission and replication (2). HDV leads to fulminant hepatitis and further disease progression among hepatitis B infected patients. The long term co-infection of HBV and HDV is associated with a higher risk of cirrhosis and hepatocellular carcinoma. Around 15\% of only HBV infected patients progress to cirrhosis versus up to $80 \%$ of HBV and HDV co-infected patients who develop cirrhosis (3). It has been estimated that almost $5 \%$ of HBV infected patients have HDV co-infection (4). The epidemiologic distribution of HDV infection differs throughout the world and in countries such as Iran (5) and in the USA varies from region to region (6). Evidences show that HDV is highly endemic in the Middle East area (7).

\section{Objectives}

Since there are few epidemiological studies in the Eastern Mediterranean Region Office of WHO (EMRO) countries and there is not any overall estimation of hepatitis D infection prevalence in this region, we designed a literature review.In order to provide a clear and comprehensive presentation of available data, we decided on a systematic review on epidemiological characteristics and on finding gap knowledge about HDV infection among $\mathrm{HBV}$ infected patients of the EMRO countries according to quantitative analysis of available epidemiological data from this region.

\section{Patients and Methods}

\subsection{Search Strategy}

We made an electronic literature search through Scopus, Web of sciences, Google scholar, Embase and two MEDLINE database engines; Pubmed and Ovid using different combinations of following key words "hepatitis D, Delta antigen, HDV, hepatitis delta virus" and the name of the EMRO countries as; Afghanistan, Bahrain, Cyprus, Djibouti, Egypt, Iran, Iraq, Jordan, Kuwait, Lebanon, Libya, Morocco, Oman, Pakistan, Palestine, Qatar, Saudi Arabia, Somalia, Sudan, Syria, Tunisia, United Arab Emirates, and Yemen. The Iranian databases such as MagIran, IranMedex and SID were also searched with relevant English and Persian key words. We searched published/unpublished information until December 2010. Search sensitivity was checked by considering duplicated papers. If the full text of articles were not accessible, e-mails were sent to authors. After one month, if authors did not give a response, informative abstracts were used for data extraction. The articles with no informative abstracts were omitted.

\subsection{Study Selection}

Published studies in English, Persian, and French were eligible if they met the following criteria:

1) Appropriate study design: cross-sectional, case-control, and case-series or cohort,

2) Studies with clearly stated information about the number of HBsAg positive patients infected with HDV in the EMRO countries. The following represents our exclusion criteria:

1) Studies with all patients having acute hepatitis B because the pattern of HDV is different in chronic and acute hepatitis.

2) Articles were about the genotypes.

3) All participants were under 15 years old.

4) Papers included HIV positive patients as participants. The names of the authors or journals had no impact on the decision to exclude or include the articles.

\subsection{Quality Assessment}

A critical appraisal (CA) was done using Epible check list form (8) to evaluate the adequacy of the sample size, design, data collection, and the resultant presentation. Each paper was appraised by two authors individually. Then, the two CA scores of each paper were compared together. If the difference was more than 10 percent, authors negotiated to reach the same CA score. Based on the total CA score, articles were divided into low $(<40 \%)$, moderate (40\% - 70\%), and high ( $>70 \%)$ quality. Low quality papers were not included in the main analysis except in subgroups analysis according to the papers' quality.

\subsection{Data Extraction}

Information was entered into Microsoft Office Excel 2007. The name of country, the author's name, the year of study, the sample size, HBsAg positive frequency, the mean age, and the total prevalence of HDV were extracted. HDV prevalence was calculated in different subgroups consisting of: 1) cirrhotic and hepatocellular carcinoma 2) asymptomatic HBsAg positive carriers consisting of inactive carriers, general population, blood donors and healthy pregnant women 3) chronic hepatitis patients and 4) high risk group including intravenous drug abusers (IDU) and hemodialysis patients. Moreover, standard errors (SE) were calculated using the following formula: $\mathrm{SE}=\sqrt{ }\left(\mathrm{P}^{*}(1-\mathrm{P}) / \mathrm{N}\right)(\mathrm{P}=$ prevalence, $\mathrm{N}=$ sample size $)$

\subsection{Statistical Analysis}

The aggregated prevalence of each country was computed by "metan" command in which is an average of the individual study results weighted by the inverse of their variances using a fix/random model (DerSimonian and Laird) based on the heterogeneity test result that was showed by Q squared, I - squared and Tau - squared statistics. For Q statistics, due to the low power of this 
test, a minimum cut-off $P$ value of 0.1 was established as a threshold of heterogeneity. I-squared lies between $0 \%$ and $100 \%$ and Tau-squared showed the variance between studies. The summary estimate of HDV prevalence in the EMRO region was calculated as an average of the pooled infection prevalence of each country weighted by the ratio of the country's HBV population to the study's sample size in the survey data analysis. Subgroup analysis was planned depending on the disease pattern (cirrhotic and hepatocellular carcinoma, asymptomatic HBsAg positive carriers, chronic hepatitis patients, and the high risk group) and quality assessment scores (low, moderate, and good). The analysis was performed with Stata 11 software (Stata Corp. LP).

\section{Results}

\subsection{Search Results}

Two hundred and four articles were found in the literature review, 145 of them were potentially related to HDV in the EMRO countries. After reviewing of the abstracts and titles, 38 articles (9-43) were omitted since they were related to the genotypes or were editorial, and review articles. In addition, three studies (42-44) with duplicated data of the same populations were excluded. In addition, sixteen citations were omitted (43-57) as they were not available online, and their abstracts did not provide sufficient information. Although we contacted their authors or publishers, their full texts were not made accessible. Eighteen studies (56-73) with all patients having acute hepatitis B were excluded and three other (74-76) studies were also omitted because all participants were children. Ten (77-86) further studies were omitted because they were categorized in a low quality group. Thus, the 62 (5, 87-143) studies to be included were identified assessing the HDV prevalence in the EMRO countries and fulfilling inclusion criteria. Out of these,19 studies (95-113) were in Iran, nine studies (129-137) in Saudi Arabia, seven studies $(5,119-124)$ in Pakistan, six studies (89-94) in Egypt, four studies (138-141) in Tunisia and Somalia (125-128) and two studies $(142,143)$ in Yemen. There was one study of other countries which consisted of: Afghanistan (87), Djibouti (88), Jordan (114), Kuwait (115), Lebanon (116), Morocco (117), and Oman (118). There were no data available from the following countries: Bahrain, Cyprus, Iraq, Libya, Palestine, Qatar, Syria, and United Arab Emirates. Three studies (127-129) had case-control design and the other 59 were cross-sectional.

\subsection{HDV Infection Prevalence Among Asymptom- atic HBsAg Positive Carriers}

Information about HDV prevalence of asymptomatic HBsAg positive carriers was available from 12 countries (Table 1). The pooled HDV prevalence among this group in the countries with more than one study was $24.6 \%$ (95\% CI: 23.66 - 29.15) in Sudan, 18.33\% (95\% CI: -2.00 - 38.65) in Pakistan (Figure 1), 15.97\% (95\% CI: $9.40-22.55)$ in Tunisia, 10.7\% (95\% CI: 0.73 - 20.87) in Egypt (Figure 2), 7.2\% (95\% CI: 4.08 - 10.32) in Saudi Arabia (Figure 3), 4.94\% (95\% CI: 3.73 - 6.15) in Iran, and 1.56\% (95\% CI: 1.10 - 2.03) in Yemen. Infection prevalence in the countries for which only one report was available ranged from $1 \%, 1.67 \%$ and $2 \%$ in Lebanon, Djibouti, and Jordan to $16.8 \%$ and $28.6 \%$ in Somalia and Afghanistan. The pooled or individual estimation of HDV prevalence in these countries provided in (Figure 4). According to the survey data analysis method, the HDV prevalence for each country was weighted using the ratio of the country's HBV population to the study's sample size. Using this method, the weighted mean HDV prevalence in the EMRO countries was 14.74\% (95\% CI: 14.73 14.77) among asymptomatic HBsAg positive group.

Table 1. Characteristics of Studies in Asymptomatic HBsAg Positive Carriers in EMRO Countries

\begin{tabular}{|c|c|c|c|c|}
\hline Name of Country & First Author/Publication, y & Quality Assessment Score & Sample Size & HDV Prevalence, $\%$ \\
\hline Afghanistan & Jacobson, Ira M./1985 & moderate & 7 & $28.60 \%$ \\
\hline \multirow[t]{4}{*}{ Djibouti } & E. A. Abbatte/1989 & moderate & 656 & $1.67 \%$ \\
\hline & El Zayadi, A./1988 & moderate & 48 & $8.30 \%$ \\
\hline & Darwish, M. A/1992 & moderate & 41 & $21.90 \%$ \\
\hline & Zaki, S/2010 & moderate & 6 & 0 \\
\hline \multirow[t]{8}{*}{ Iran } & Malekzadeh, R./1989 & moderate & 158 & $13.90 \%$ \\
\hline & Rezvan, H./1990 & moderate & 120 & $2.50 \%$ \\
\hline & Amini, S./1993 & good & 123 & $2.40 \%$ \\
\hline & Habibi, F/2000 & moderate & 200 & $9.00 \%$ \\
\hline & Karimi, A./2000 & moderate & 154 & $1.30 \%$ \\
\hline & Hassanjani Roshan, M. R./2004 & moderate & 546 & $2.00 \%$ \\
\hline & Alavian, S.M./2004 & moderate & 102 & $2.00 \%$ \\
\hline & Roshandel, G/2007 & good & 139 & $5.80 \%$ \\
\hline
\end{tabular}




\begin{tabular}{|c|c|c|c|c|}
\hline & Amini, S/2007 & moderate & 79 & $8.00 \%$ \\
\hline & Taghvaei, T/2008 & moderate & 167 & $0 \%$ \\
\hline & Doosti, A./2009 & moderate & 200 & $3.00 \%$ \\
\hline & Somi, M. H/2009 & moderate & 300 & $4.70 \%$ \\
\hline & Hajiani, E/2009 & good & 1725 & $3.59 \%$ \\
\hline & Ataei, B./2010 & good & 346 & $2.80 \%$ \\
\hline & Alizadeh, A. H./2010 & moderate & 48 & 20.80 \\
\hline & Jedary Seifi, S./2010 & moderate & 355 & $6.00 \%$ \\
\hline Jordan & Toukan, A. U/1987 & good & 136 & $2.00 \%$ \\
\hline Lebanon & Ramia, S/2007 & moderate & 107 & $0.90 \%$ \\
\hline \multirow[t]{3}{*}{ Pakistan } & Saeed Ur, R/2000 & moderate & 20 & $10.00 \%$ \\
\hline & Baig, S/2009 & moderate & 38 & $7.98 \%$ \\
\hline & Seetlani, N.K/2009 & moderate & 143 & $37.00 \%$ \\
\hline Somalia & Aceti, A/1989 & moderate & 220 & $16.80 \%$ \\
\hline \multirow[t]{6}{*}{ Saudi Arabia } & Ashraf, S. J/1986 & moderate & 102 & $6.60 \%$ \\
\hline & Ramia, S/1988 & moderate & 465 & $7.95 \%$ \\
\hline & Sheth, K. V.|1989 & moderate & 490 & $11.20 \%$ \\
\hline & El Nasser, M. N./1992 & moderate & 256 & $11.40 \%$ \\
\hline & Fathalla, S. E/1994 & moderate & 182 & $2.75 \%$ \\
\hline & Al Traif, I/2004 & moderate & 60 & $3.30 \%$ \\
\hline \multirow[t]{2}{*}{ Sudan } & Al-Arabi, M. A./1987 & moderate & 20 & $25.00 \%$ \\
\hline & Hyams, K. C./1989 & good & 115 & $27.80 \%$ \\
\hline \multirow[t]{4}{*}{ Tunisia } & Jenhani, F/1990 & moderate & 45 & $33.00 \%$ \\
\hline & Triki, H/1997 & moderate & 650 & $16.10 \%$ \\
\hline & Skouri, H/2004 & moderate & 139 & $8.00 \%$ \\
\hline & Djebbi, A./2009 & moderate & 176 & $6.80 \%$ \\
\hline \multirow[t]{2}{*}{ Yemen } & El Guneid, A. M./1993 & moderate & 150 & $1.33 \%$ \\
\hline & Scott, D. A/1990 & moderate & 112 & $1.80 \%$ \\
\hline
\end{tabular}

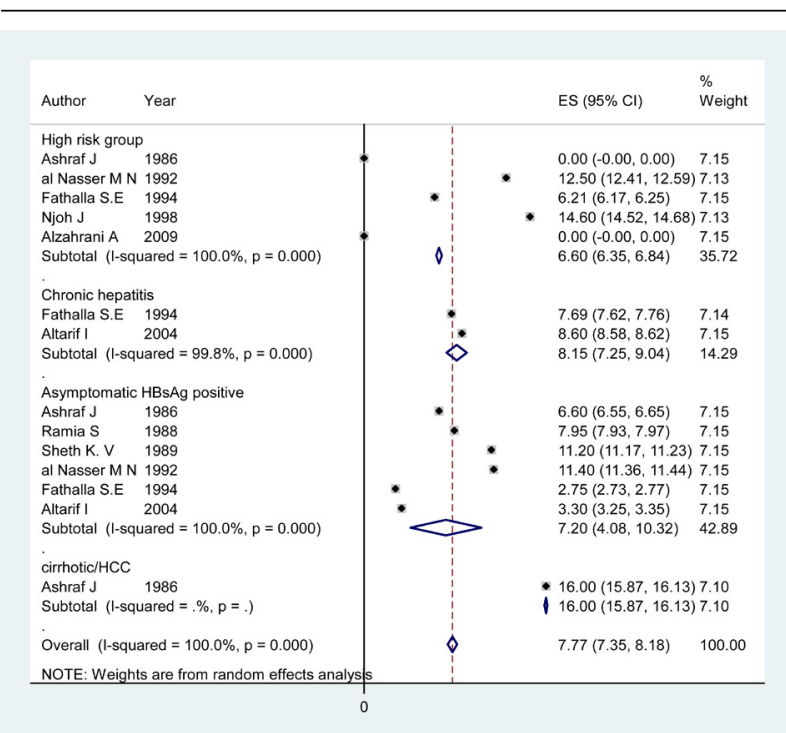

Figure 1. Forest Plot of HDV Infection Prevalence among Different Subgroups in Pakistan

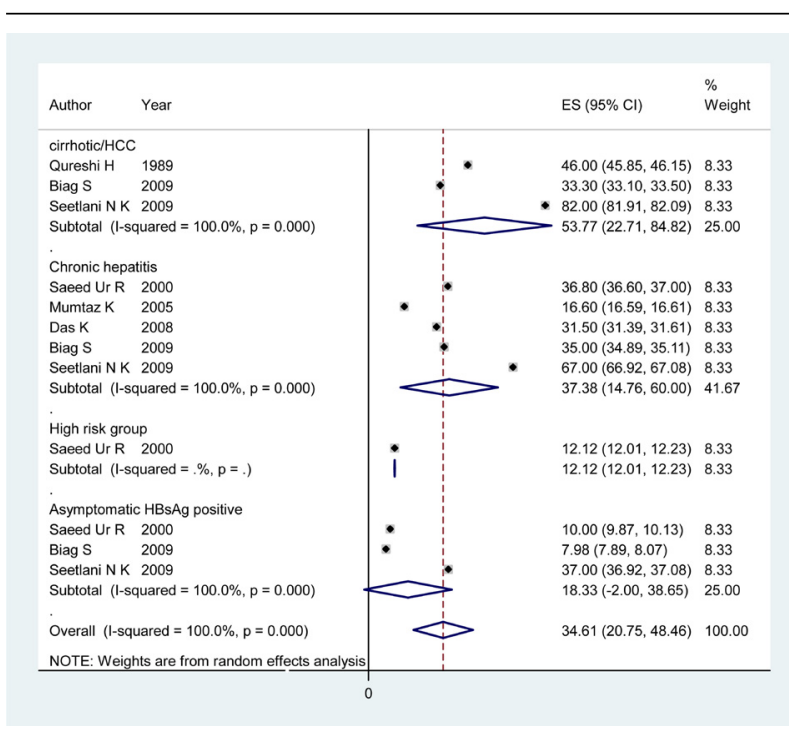

Figure 2. Forest Plot of HDV Infection Prevalence among Different Subgroups in Egypt 


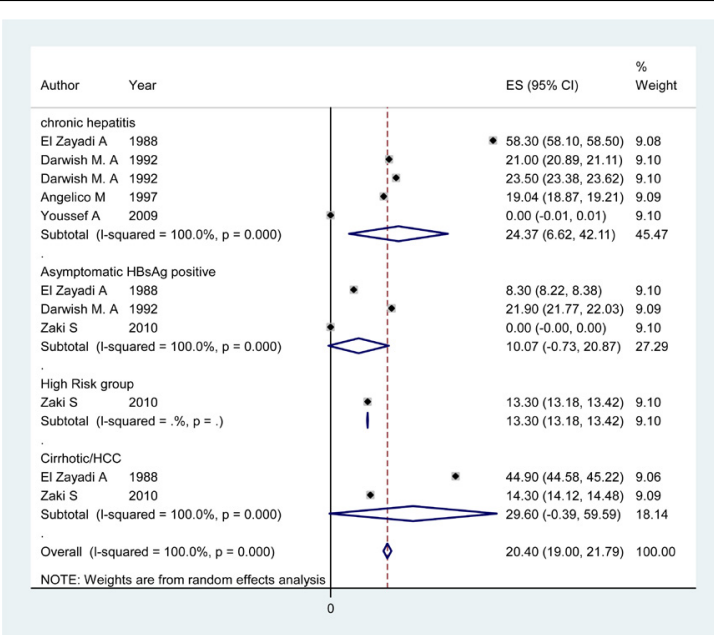

Figure 3. Forest Plot of HDV Infection Prevalence among Different Subgroups in Saudi Arabia

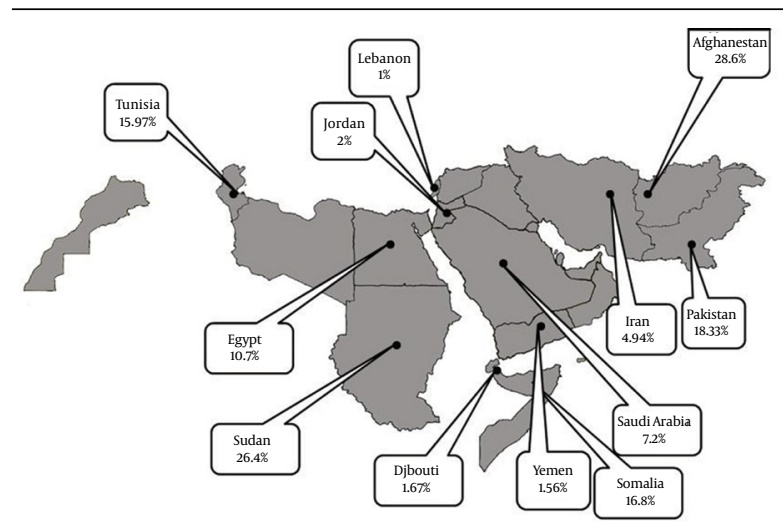

Figure 4. Regional Distribution of Pooled or Individual Prevalence of Hepatitis D Virus Infection among Asymptomatic HBsAg Positive in EMRO Countries

Table 2. Characteristics of Studies among Patients with Chronic Hepatitis Disease in EMRO Countries

\begin{tabular}{|c|c|c|c|c|}
\hline Name of Country & $\begin{array}{l}\text { First Author/Publica- } \\
\text { tion, } \mathbf{y}\end{array}$ & $\begin{array}{l}\text { Quality Assessment } \\
\text { Score }\end{array}$ & Sample Size & HDV Prevalence, \% \\
\hline \multirow[t]{5}{*}{ Egypt } & El Zayadi, A./1988 & moderate & 24 & $58.30 \%$ \\
\hline & Darwish, M. A/1992 & moderate & 51 & $21.00 \%$ \\
\hline & Darwish, M. A/1992 & good & 51 & $23.50 \%$ \\
\hline & Angelico M/1997 & moderate & 21 & $19.04 \%$ \\
\hline & Youssef A/2009 & moderate & 10 & $0 \%$ \\
\hline \multirow[t]{7}{*}{ Iran } & Rezvan, H./1990 & moderate & 5 & $0 \%$ \\
\hline & Alavian, S.M./2004 & moderate & 155 & $7.70 \%$ \\
\hline & Taghavi, S. A./2008 & good & 93 & $9.70 \%$ \\
\hline & Somi, M. H/2009 & moderate & 547 & $12.70 \%$ \\
\hline & Hajiani, E/2009 & good & 88 & $45.50 \%$ \\
\hline & Alizadeh, A. H./2010 & moderate & 30 & $13.30 \%$ \\
\hline & Zahedi, MJ/2010 & good & 196 & $10.70 \%$ \\
\hline Jordan & Toukan, A. U/1987 & good & 42 & $21.42 \%$ \\
\hline Kuwait & Alkandari, S./1988 & moderate & 48 & $31.00 \%$ \\
\hline Lebanon & Ramia, S/2007 & moderate & 92 & $2.17 \%$ \\
\hline Morocco & Rioche, M/1987 & moderate & 85 & $1.00 \%$ \\
\hline \multirow[t]{5}{*}{ Pakistan } & Saeed Ur, Rahman/2000 & moderate & 22 & $36.80 \%$ \\
\hline & Mumtaz, K./2005 & good & 8721 & $16.60 \%$ \\
\hline & Das, K./2008 & moderate & 73 & $31.50 \%$ \\
\hline & Seetlani, N.K/2009 & moderate & 141 & $67.00 \%$ \\
\hline & Baig, S/2009 & moderate & 70 & $35.00 \%$ \\
\hline \multirow[t]{2}{*}{ Somalia } & Aceti, A/1991 & moderate & 41 & $56.10 \%$ \\
\hline & Bile, K/1993 & moderate & 44 & $38.60 \%$ \\
\hline \multirow[t]{2}{*}{ Saudi Arabia } & Fathalla, S. E/1994 & moderate & 52 & $7.69 \%$ \\
\hline & Al Traif, I./2004 & moderate & 780 & $8.60 \%$ \\
\hline Tunisia & Djebbi, A./2009 & moderate & 39 & $38.40 \%$ \\
\hline Yemen & el Guneid, A. M./1993 & moderate & 25 & $4.00 \%$ \\
\hline
\end{tabular}




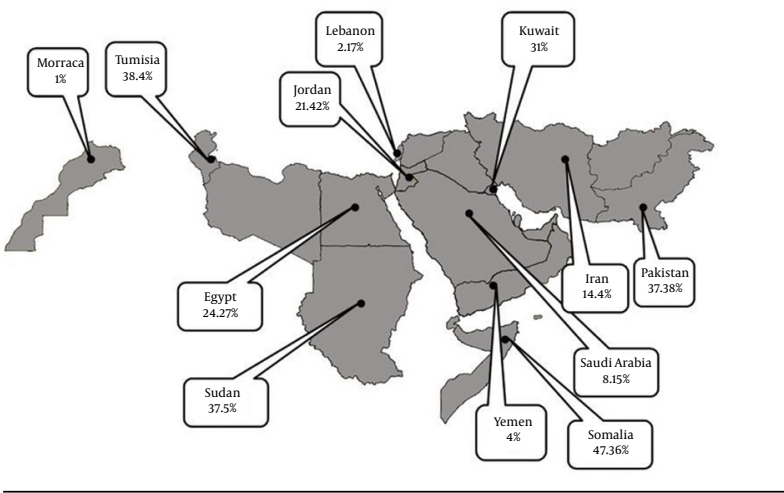

Figure 5. Regional Distribution of Pooled or Individual Prevalence of Hepatitis D Virus Infection among Patients with Chronic Liver Disease at EMRO Countries

\subsection{HDVInfection Prevalence Among Patients With Chronic Hepatitis}

Articles of 12 countries revealed information on the HDV infection rate among patients with chronic hepatitis (Table 2). The pooled HDV prevalence was $47.36 \%$ (95\% CI: 30.24 - 64.49) in Somalia, 37.38\% (95\% CI: 14.76 - 60) in Pakistan (Figure 1), 24.37\% (95\% CI: 6.62 - 42.11) in Egypt (Figure 2), 14.4\% (95\% CI: 7.72 - 21.07) in Iran, and 8.15\% (95\% CI: 7.25 - 9.04) in Saudi Arabia (Figure 3). The pooled or individual estimation of HDV prevalence among chronic hepatitis patients demonstrated in Figure 5. The weighted mean HDV prevalence was $27.8 \%$ (95\% CI: 27.78 - 27.82) in the EMRO countries.

Table 3. Characteristics of Studies in Cirrhotic/HCC Patients and High Risk Group in EMRO Countries

\begin{tabular}{|c|c|c|c|c|c|c|}
\hline \multirow{2}{*}{$\begin{array}{l}\text { Name of } \\
\text { Country }\end{array}$} & \multirow{2}{*}{$\begin{array}{l}\text { First Author/Publi- } \\
\text { cation, y }\end{array}$} & \multirow{2}{*}{$\begin{array}{l}\text { Quality Assess- } \\
\text { ment Score }\end{array}$} & \multicolumn{2}{|c|}{ Cirrhotic/HCC Patients } & \multicolumn{2}{|c|}{ High Risk Group } \\
\hline & & & Sample Size & HDV Prevalence, \% & Sample Size & HDV Prevalence, \% \\
\hline \multirow[t]{2}{*}{ Egypt } & el Zayadi, A./1988 & moderate & 9 & $44.90 \%$ & & \\
\hline & Zaki, S/2010 & moderate & 14 & $14.30 \%$ & 30 & $13.30 \%$ \\
\hline \multirow[t]{7}{*}{ Iran } & Karimi, A./2000 & moderate & 71 & $50.00 \%$ & 65 & $2.00 \%$ \\
\hline & Alavian, S.M./2004 & moderate & 23 & $8.70 \%$ & & \\
\hline & Makvandi, M/2004 & moderate & 16 & $20.00 \%$ & & \\
\hline & Taghavi, S. A./2008 & good & & & 15 & $26.60 \%$ \\
\hline & Hajiani, E/2009 & good & 88 & $43.20 \%$ & & \\
\hline & Jedary Seifi, S./2010 & moderate & & & 190 & $8.94 \%$ \\
\hline & Alizadeh, A. H./2010 & moderate & & & 7 & $28.57 \%$ \\
\hline Jordan & Toukan, A. U/1987 & good & 52 & $51.30 \%$ & & \\
\hline Lebanon & Ramia, S/2007 & moderate & 35 & 0 & 20 & 0 \\
\hline Oman & $\begin{array}{l}\text { Aghanashinikar, P. } \\
\text { N./1992 }\end{array}$ & moderate & & & 22 & $13.63 \%$ \\
\hline \multirow[t]{4}{*}{ Pakistan } & Qureshi, H./1989 & moderate & 45 & $46.00 \%$ & & \\
\hline & $\begin{array}{l}\text { Saeed Ur, Rah- } \\
\text { man/2000 }\end{array}$ & moderate & & & 33 & $12.12 \%$ \\
\hline & Baig, S/2009 & moderate & 21 & $33.00 \%$ & & \\
\hline & Seetlani, N.K/2009 & moderate & 78 & $82.00 \%$ & & \\
\hline \multirow[t]{2}{*}{ Somalia } & Bile, K/1991 & moderate & 23 & $39.10 \%$ & & \\
\hline & Aceti, A/1991 & moderate & 11 & $27.30 \%$ & & \\
\hline \multirow{6}{*}{$\begin{array}{l}\text { Saudi } \\
\text { Arabia }\end{array}$} & Ashraf, S. J/1986 & moderate & & & 6 & 0 \\
\hline & Ashraf, S. J/1986 & moderate & 30 & $16.00 \%$ & & \\
\hline & al Nasser, M. N./1992 & moderate & & & 50 & $12.50 \%$ \\
\hline & Fathalla S.E/1994 & moderate & & & 177 & $6.21 \%$ \\
\hline & Njoh, J./1998 & moderate & & & 75 & $14.60 \%$ \\
\hline & Alzahrani, A. J./2009 & moderate & & & 41 & 0 \\
\hline Tunisia & Jenhani, F/1990 & moderate & 114 & $21.00 \%$ & & \\
\hline
\end{tabular}




\subsection{HDV Infection Prevalence Among Cirrhotic/ HCC Patients and High Risk Group}

Table 3 showed information about HDV prevalence among both cirrhotic/HCC patients and high risk groups. The pooled HDV prevalence among cirrhotic/HCC patients was 53.77\% (95\% CI: 22.71 - 82.84) in Pakistan (Figure 1), 33.20 (95\% CI: 21.64 - 44.76) in Somalia, $30.47 \%$ ( 95\% CI: 9.76 - 51.19) in Iran and 29.6\% (95\% CI: -0.39 -59.59) in Egypt (Figure 2). The weighted mean HDV prevalence of patients with cirrhosis or hepatocellular carcinoma was $36.57 \%$ (95\% CI: 36.55 - 36.59) among nine countries revealing information on the HDV infection rate in cirrhotic/HCC patients. In the high risk group consisting of IDU and hemodialysis patients, the weighted mean HDV prevalence in six countries was $16.44 \%$. (95\% CI: $16.42-16.46$ ).

\subsection{HDV Prevalence According to Quality Assess- ment Score}

According to the quality assessment score, ten articles were categorized in the good quality group $(5,29,91,97$, $99,102,109,111,113,114)$. In this group, HDV prevalence was $16.25 \%, 16.60 \%, 44.32 \%$ among asymptomatic HBsAg positive carriers, chronic hepatitis patients and cirrhotic/HCC patients, respectively. HDV prevalence in moderate qual- ity group consisted of 52 articles (87-90, 92-96, 98, 100, $101,103-108,110,112,115-145)$ among asymptomatic HBsAg positive carrier was $14.02 \%$ and among chronic hepatitis patients was $28.73 \%$. In cirrhotic/HCC and high risk group, HDV prevalence was $36 \%$ and $16.44 \%$. In low quality group, we had ten articles (77-86). The HDV prevalence was 44.50\%, 22.67\%, and 59.44\% among asymptomatic HBsAg positive carriers, chronic hepatitis, and cirrhotic/HCC patients, respectively. We had no data among the high risk group in low quality and good quality articles.

\subsection{Chronologic Changes of HDV Prevalence}

To detect the HDV prevalence pattern over the years in the EMRO countries, we sorted HDV infection prevalence by year for each country. This analysis also was repeated for the whole EMRO region. The data was not shown; however, no specific pattern was seen. The overall estimation for three age categories $(<20,20-30,>30)$ was calculated in different populations (asymptomatic HBsAg positive persons, chronic hepatitis, cirrhotic and hepatocellular carcinoma). Due to lack of information for most countries, this table was not shown in the results. The only recognizable patterns was the increase of HDV prevalence in Saudi Arabia by year among the asymptomatic HBsAg positive group and decrease of infection prevalence by year in Iran of the same group.

Table 4. Correlation Among HBeAg, ALT, and HBV-DNA

\begin{tabular}{|c|c|c|c|c|}
\hline Author (Citation) & Country & Prevalence,\% & $\begin{array}{l}\text { Sample Size, Target } \\
\text { Population }\end{array}$ & $\begin{array}{l}\text { Neighbors City in EMRO Region, } \\
\text { Prevalence }\end{array}$ \\
\hline \multicolumn{5}{|l|}{ African Region } \\
\hline Nwokediuko S (154) & Nigeria & $15.60 \%$ & $\begin{array}{l}\text { Asymptomatic HBsAg } \\
\text { positive }\end{array}$ & Libya (no data) \\
\hline Rapicetta M (155) & Ethiopia & $5.80 \%$ & $\begin{array}{l}\text { Asymptomatic HBsAg } \\
\text { positive }\end{array}$ & Sudan $(26.40 \%)$ \\
\hline $\begin{array}{l}\text { Foupouapouognigni } \\
\mathrm{Y}(156)\end{array}$ & Cameroon & $17.60 \%$ & $\begin{array}{l}\text { Asymptomatic HBsAg } \\
\text { positive }\end{array}$ & None \\
\hline \multicolumn{5}{|l|}{ Americas Region } \\
\hline Fonseca JC (147) & Brazil & $34.40 \%$ & $\begin{array}{l}\text { Asymptomatic HBsAg } \\
\text { positive }\end{array}$ & None \\
\hline Hadler S. C (148) & Venezuela & $34.00 \%$ & $\begin{array}{l}\text { Asymptomatic HBsAg } \\
\text { positive }\end{array}$ & None \\
\hline \multicolumn{5}{|l|}{$\begin{array}{l}\text { South-East Asia } \\
\text { Region }\end{array}$} \\
\hline Kim H.S (157) & Korea & $0.32 \%$ & Chronic hepatitis & None \\
\hline Chakraborty P (158) & India & $8.10 \%$ & Chronic hepatitis & Pakistan (37.38\%) \\
\hline \multicolumn{5}{|l|}{ European Region } \\
\hline Degertekin H (149) & Turkey/middle east & $27.10 \%$ & Meta analysis & $\operatorname{Iran}(4.94 \%)$ \\
\hline Gaeta GB (6) & Italy/Europe & $8.30 \%$ & Chronic hepatitis & None \\
\hline \multicolumn{5}{|l|}{$\begin{array}{l}\text { Western Pacific } \\
\text { Region }\end{array}$} \\
\hline Chen X (159) & China & $3.16 \%$ & $\begin{array}{l}\text { Asymptomatic HBsAg } \\
\text { positive }\end{array}$ & Afghanistan (28.60\%) \\
\hline Tsatsralt-Od B (150) & Mongolia & $43.00 \%$ & Chronic hepatitis & None \\
\hline
\end{tabular}




\section{Discussion}

The result of this study revealed HDV prevalence was 15\% and $26 \%$ among asymptomatic HBsAg positive carriers and chronic hepatitis patients, respectively. This result indicates HDV infection is endemic in the EMRO region. In addition, the most prevalence of HDV infection was in African countries of EMRO regions such as Egypt, Sudan, Tunisia and Somalia. As a result, North Africa must be considered as a high HDV prevalence area in addition to central Africa, southern America, and Mediterranean countries since they were mentioned in the previous studies (146). The comparison of HDV prevalence between different WHO regions was demonstrated in Table 4. In the African region, the infection prevalence is near to mean of the HDV prevalence in the EMRO region. In other regions, some countries such as Brazil (147), Venezuela (148), Turkey (149), and Mongolia (150) have higher HDV infection prevalence in comparison with the EMRO countries. Our analysis showed that a cirrhotic/HCC group had the most HDV infection prevalence when correlated with a previous study which has consistently shown most patients with HBV and HDV co-infection have a more severe progression to cirrhosis and HCC $(151,152)$. Furthermore, HDV infection prevalence was calculated to be $16 \%$ among IDU and hemodialysis group (high risk group) that is less common in comparison with asymptomatic and chronic hepatitis patients. This result is in contrast with previous studies $(146,153)$ and indicates that IDU and people exposed to blood and its products were at a high risk of acquiring HDV infection. This result may be due to our limited existing data among IDU and hemodialysis group. The analysis according to the quality assessment score showed that HDV prevalence was overestimated among asymptomatic HBsAg positive carriers in low quality articles. Also, this prevalence was underestimated among chronic hepatitis patients. Furthermore, the subject of HDV infection prevalence in good quality articles was closed to overall estimation. We had some limitations in our review such as lack of good coverage caused by hand searching the library and dissertations. Also, for most of the countries, our literature review was limited to English. As a result, the information in native languages was not operational. Another limitation was related to HDV detection method which was ELISA for most articles. Hence, the confirmation of ongoing HDV infection by PCR testing of HDV RNA was missing. The impact of this lack of information is that patients with and without active delta infection cannot be differentiated. One of our goals in this systematic review was the calculation of a pooled estimation for possible risk factors to identify the most important routes of HDV transmission in the EMRO region. However, the numbers of articles that revealed information in this field were rare. Therefore, we could not perform that analysis. Many articles were done before the year 2000 and some countries had one or two
HDV prevalence estimations in close time points. Due to lack of information, a recognizable pattern of HDV prevalence was not detectable during recent years. In addition, most studies were performed on young adults (30-50) therefore; we could not access the impact of age on HDV acquisition in the EMRO region. One of the strengths of this study was doing the survey data analysis in addition to usual 'Meta' command that helps increase generalizability of results to the whole population. Twenty two countries (total population is $798,782,000$ ) are in the EMRO region and the data from $92 \%(738,901,000)$ of this population was used in our analysis. In conclusion, the HDV infection is endemic in the EMRO countries; and this prevalence is very high in African part of the EMRO region. Furthermore, it is more common among patients who have a severe form of hepatitis. Due to these results, we would recommend blood screening for HDV infection. Furthermore, new surveys are needed to detect infection prevalence in different points of time and to provide the updated data about HDV prevalence in the EMRO region countries.

\section{Acknowledgements}

None declared.

\section{Authors' Contribution}

Amini $\mathrm{N}$ made an electronic literature search. A critical appraisal (CA) was done by Saiedi Hosseini SY, AalaeiAndabili SH and Amini N. Kabir A and Amini N analysed the data. All the authors contributed in interpration of results. Alavian SM and Rizzetto M read the aricle and supervised the team.

\section{Financial Disclosure}

None declared.

\section{Funding/Support}

None declared.

\section{References}

1. Rizzetto M, Canese MG, Arico S, Crivelli O, Trepo C, Bonino F, et al Immunofluorescence detection of new antigen-antibody system (delta/anti-delta) associated to hepatitis B virus in liver and in serum of HBsAg carriers. Gut.1977;18(12):997-1003.

2. Hajiani E, Hashemi S, Jalali F. Seroprevalence of Delta Hepatitis in Patients with Chronic Hepatitis B and its Clinical Impact in Khuzestan Province, Southwest Iran. Hepat Mon.2009;9(4):28792.

3. Yamaguchi Y, Delehouzee S, Handa H. HIV and hepatitis delta virus: evolution takes different paths to relieve blocks in transcriptional elongation. Microbes Infect.2002;4(11):1169-75.

4. Taghavi SA, Sedighi S, Mehrabani D, Khademolhosseini F. Hepatitis D in Chronic Active Hepatitis B: Prevalence, Liver Enzyme Levels and Histopathology- an Epidemiological Study in Shiraz, Southern Iran, 2003-2004. Hepat Mon.2008;8(4):248-51.

5. Mumtaz K, Hamid SS, Adil S, Afaq A, Islam M, Abid S, et al. Epidemiology and clinical pattern of hepatitis delta virus infection in 
Pakistan.J Gastroenterol Hepatol.2005;20(10):1503-7.

6. Gaeta GB, Stroffolini T, Chiaramonte M, Ascione T, Stornaiuolo G Lobello S, et al. Chronic hepatitis D: a vanishing Disease? An Italian multicenter study. Hepatology.2000;32(4 Pt 1):824-7.

7. Husa P, Linhartova A, Nemecek V, Husova L. Hepatitis D. Acta Virol.2005;49(4):219-25.

8. Glynn L. EBLIP Critical Appraisal Checklist. Memorial University of Newfoundland; Available from: http://www.nihs.ie/pdf/EBL\%20 Critical\%20Appraisal\%20Checklist.pdf.

9. Abbas Z, Jafri W, Raza S. Hepatitis D: Scenario in the Asia-Pacific region. World J Gastroenterol.2010;16(5):554-62.

10. Alavian SM. We Have More Data Regarding Epidemiology of Hepatitis D in Iran but There are Defects to be Filled Yet! Hepat Mon.2008;8(4):245-7.

11. Alavian SM. Hepatitis D Is a Forgotten Problem in Hemodialysis Patients in the World. Hepat Mon.2008;8(1):9-10.

12. Alavian SM. Hepatitis D in hemodialysis setting: A short Review. Acta Med Sal.2009;38(2):59-62.

13. Alavian SM. Unthought of Problems Regarding Hepatitis D Virus Infection. Hepat Mon.2010;10(2):77-9.

14. Alavian SM, Alavian SH. Hepatitis D virus Infection; Iran, Middle East and Central Asia. Hepat Mon.2005;5(4):137-43.

15. Aly MA, Mangood AM, Essa MH, Refaat MA, Helmy E, Makarem SS The pattern of bilharzial infection with hepatitis B virus associated with delta agent. J Egypt Soc Parasitol.1989;19(2 Suppl):869-78.

16. Behzadian F, Sabahi F, Karimi M, Sadeghizadeh M, Maghsoudi N, Forooshani RS, et al. Molecular phylogenetic analysis of Iranian HDV complete genome. Virus Genes.2005;30(3):383-93.

17. Behzadian F, Sabahia F, Sadeghizadeh M, Maghsoudi N, Fotouhi Chahooki F, Karimi M. In vitro Replication of Hepatitis D Virus Using a New Construct Containing a cDNA Dimer of HDV Genome. Intervirology.2007;50(6):387-393.

18. Bhat SK, Sachdeva VN, Saleem HI. Profile of viral hepatitis patients in Dakhliya, Oman. Saudi Med J.2005;26(5):819-23.

19. Chao YC, Tang HS, Hsu CT. Evolution rate of hepatitis delta virus RNA isolated in Taiwan.J Med Virol.1994;43(4):397-403.

20. el-Dep HA, Hashim E, el-Tabakh S. Epidemiology of non A non $B$ hepatitis in Jeddah, KSA with special reference to aminotransferases as a prognostic criterion. J Egypt Public Health Assoc.1989;64(1-2):155-68.

21. el-Zimaity DM, Hyams KC, Imam IZ, Watts DM, Bassily S, Naffea EK, et al. Acute sporadic hepatitis $\mathrm{E}$ in an Egyptian pediatric population. Am J Trop Med Hyg.1993;48(3):372-6.

22. Elzouki ANY. Hepatitis D virus. Annals of Saudi Medicine.1996;16(2):184-192.

23. Esmaeili R, Alavian SM, Hajibeigi B, Sabouri E, Edalat R, Adeli A, et al. Phylogenetic analysis of twenty-six cases of hepatitis delta virus isolates in Tehran, Iran. Hepat Mon.2009;9(3):196-200.

24. Faustini A, Franco E, Saitto C, Cauletti M, Zaratti L, Papini P, et al. Hepatitis A, B, C and D in a community in Italy of immigrants from NE Africa. J Public Health Med.1994;16(1):71-8.

25. Fong TL, DeCock KM, Govindarajan S, Yamada S, Morgan TR, Redeker AG. Clustering of delta hepatitis in a family from Lebanon. Infect Dis.1986;154(5):912-3.

26. Gomatos PJ, Monier MK, Arthur RR, Rodier GR, el-Zimaity D, Hassan NF, et al. Sporadic acute hepatitis caused by hepatitis E virus in Egyptian adults. Clin Infect Dis.1996;23(1):195-6.

27. Hannachi $\mathrm{N}$, Bahri O, Boukatef $\mathrm{B}$, Triki H, Boukadida J. Isolated anti-HBc profile should be investigated in a country of intermediate endemicity for hepatitis B. Clin Microbiol Infect.2010;16:S306.

28. Huo TI, Wu JC, Lai CR, Lu CL, Sheng WY, Lee SD. Comparison of clinico-pathological features in hepatitis B virus-associated hepatocellular carcinoma with or without hepatitis D virus superinfection.J Hepatol.1996;25(4):439-44.

29. Hyams KC, al-Arabi MA, al-Tagani AA, Messiter JF, al-Gaali AA George JF. Epidemiology of hepatitis B in the Gezira region of Sudan. Am JTrop Med Hyg.1989;40(2):200-6.

30. Khuroo MS. Viral hepatitis in international travellers: risks and prevention. Int J Antimicrob Agents.2003;21(2):143-52.

31. Mirshafiee H, Mahmoodian-Shooshtari M, Sharifi Z, Hosseini SM. Genotype Analysis of Hepatitis Delta Virus from Hepatitis B
Surface Antigen-Positive Patients Using PCR-RFLP in Tehran, Iran. Arch Iran Med.2009;12(3):238-43.

32. Mahoney FJ. Update on Diagnosis, Management, and Prevention of Hepatitis B Virus Infection. Clin. Microbiol. Rev.1999;12(2):35166.

33. Moatter T, Abbas Z, Shabir S, Jafri W. Clinical presentation and genotype of hepatitis delta in Karachi. World J Gastroenterol.2007;13(18):2604-7.

34. Mohebbi SR, Zali N, Derakhshan F, Tahami A, Mashayekhi R, Amini-Bavil-Olyaee S, et al. Molecular epidemiology of hepatitis delta virus (HDV) in Iran: A preliminary report. $J$ Med Virol.2008;80(12):2092-9.

35. Qureshi H, Arif A, Alam E. Treatment of HBV and HDV co-infection using lamivudine. JAyub Med Coll Abbottabad.2009;21(2):1-3.

36. Riaz A, Zuberi SJ, Qureshi H, Alam SE. Delta hepatitis in Pakistan. Trop Doct.2005;35(2):121.

37. Saudy N, Sugauchi F, Tanaka Y, Suzuki S, Aal AA, Zaid MA, et al. Genotypes and phylogenetic characterization of hepatitis $B$ and delta viruses in Egypt. J Med Virol.2003;70(4):529-36.

38. Shahinsaz L, Sabahi F, Karami M, Behzadian F, Alavian S.M, Zand V. Detection and genotyping of hepatitis D virus from HBsAg positive patients in Iran using RT-PCR. Iran J Biotech.2006;4(3):174-9.

39. Toukan AU, al-Kandari $\mathrm{S}$. The role of hepatitis D virus in liver disease in the Middle East. Prog Clin Biol Res.1991;364:63-8.

40. Wallace MR, Hale BR, Utz GC, Olson PE, Earhart KC, Thornton SA, et al. Endemic Infectious Diseases of Afghanistan. Clin Infect Dis.2002;34(Suppl 5):S171-S207.

41. Zaki Mel S, Salama OS, Mansour FA, Hossein S. Hepatitis E virus coinfection with hepatotropic viruses in Egyptian children. J Microbiol Immunol Infect.2008;41(3):254-8.

42. Zhang YY, Tsega E, Hansson BG. Phylogenetic analysis of hepatitis $D$ viruses indicating a new genotype I subgroup among African isolates. J Clin Microbiol.1996;34(12):3023-30.

43. Zuberi BF, Quraishy MS, Afsar S, Akhtar N, Kumar A, Dodani SK. Treatment outcome in patients of hepatitis B with hepatitis D: experience of 4 years at a tertiary care centre in Pakistan. J Coll Physicians Surg Pak.2007;17(6):320-2.

44. Gholamreza R, Shahryar S, Abbasali K, Hamidreza J, Abdolvahab M, Khodaberdi K, et al. Seroprevalence of hepatitis B virus and its co-infection with hepatitis D virus and hepatitis $C$ virus in Iranian adult population. Indian J Med Sci.2007;61(5):263-8.

45. Rezvan H, Forouzandeh B, Taroyan S, Fadaei S, Azordegan F. Epidemiology of Delta virus infection and its clinical impact in Iran. J Iran Med Council.1991;3(10):171-8.

46. Roshandel G, Semnani S, Abdolahi N, Besharat S, Keshtkar AA Joshaqani $\mathrm{H}$, et al. Prevalence of hepatitis D virus infection in hepatitis B surface antigen-positive subjects in Golestan province, northeast Iran. J Microbiol Immunol Infect.2008;41(3):227-30.

47. Ali HYM, Yassen SA. Prevalence of hepatitis B \& D viral infections among hospital personnel in Mosul-Iraq. Qatar Med J.2001;10(2):51-3.

48. Arya SC, Ashraf SJ, Pathak VP, Nanda V, Parande CM, Tajuddin S. Serological profiles for HBV, HDV, HIV-1 and HTLV-1 in Saudi patients with a malignancy.J Commun Dis.1991;23(4):270-5.

49. Ashraf SJ, Arya SC, Arendrup M, Krogsgaard K, Parande CM, Orskov B, et al. Frequencies of hepatitis B, delta and HTLV-III virus markers in Saudi Arabia. Liver.1986;6(2):73-7.

50. Eleftheriou A, Teloni F, Ioannou P. HDV infection in Cyprus. Prog Clin Biol Res.1993;382:277-85.

51. el-Hawey AM, Abdel-Rahman MM, Ibrahim MS, Abdel-Rahman $\mathrm{AH}$, Salama MM. Delta virus versus HBsAg in chronic active hepatitis and their relation to clinical, laboratory, and morbidity findings in bilharzial and non-bilharzial patients. J Egypt Soc Parasitol.1993;23(1):151-60.

52. el-Hazmi MA, Ramia S. Frequencies of hepatitis B, delta and human immune deficiency virus markers in multitransfused Saudi patients with thalassaemia and sickle-cell disease. I Trop Med Hyg.1989;92(1):1-5.

53. el-Hazmi MA, Ramia S. Epidemiology of delta agent infection in Arabia: geographical distribution and prevalence of anti-delta. Vox Sang.1986;50(4):216-9. 
54. Malik IA, Ahmed A, Iqbal M, Legters LJ, Luqman M, Akhtar MA. Infection with delta agent in Pakistan. Introduction of a new hepatitis agent. J Pak Med Assoc.1988;38(5):126-8.

55. Massoud M, Helmy O, Saleh WA. Hepatitis D anti-bodies in some HBs Ag positive in Saudis at Riyadh. J Egypt Soc Parasitol.1991;21(2):561-5.

56. Safer L, Ben Chaabene N, Melki W, Saffar H. Epidemiology of viral hepatitis in Tunisia. Rev Epidemiol Sante Publique.2006;54(4):377-80.

57. Shobokshi OA, Serebour FE. Prevalence of delta antigen/antibody in various HBsAg positive patients in Saudi Arabia. Prog Clin Bio Res.1987;234:471-5.

58. Torabi S, Ebrahimpoor S, Maljaei S, Naghili B. Seroepidemiological studies of Hepatitis Delta (HDV) in HBsAg positive individuals in Tabriz. JUrmia Univ Med Sci.2003;13(4):290-7.

59. Triki H. Epidemiology of hepatitis $B$ virus, hepatitis $C$ virus and Delta virus in the general population and in liver cirrhosis in $\mathrm{Tu}$ nisia. Arch Inst Pasteur Tunis.1994;71(3-4):403-6.

60. Zahedi M. Serologic prevalence of hepatitis D in HBsAg positive patients in Kerman, south of Iran, 2002-2003. Kerman Univ Med Sci Health Serv.2003; p.

61. Abdel-Wahab KS, Abu-Shady EA. Evidence of a 1985-1987 outbreak of acute and chronic hepatitis in Egypt caused by a mutant hepatitis-B virus detected by spot-DNA hybridization test.J Egyp Public Health Assoc.1992;67(1-2):181-93.

62. Zuberi SJ. The delta agent and hepatitis-D. J Pak Med Assoc.1988;38(11):283.

63. Al-Kandari S, Nordenfelt E, Al-Nakib B, Radakrishnan S, AlNakib W. Acute non-A, non-B hepatitis in Kuwait. Scand J Infect Dis.1987;19(6):611-6

64. Al-Kandari S, Nordenfelt E, Al-Nakib B, Hansson BG, Ljunggren K, Al-Nakib W. Hepatitis delta virus infection in acute hepatitis in Kuwait. Scand J Infect Dis.1988;20(1):15-9.

65. Ayed K, Gorgi Y, Pichoud C, Trepo C. Prevalence of HD Ag and anti HD by radioimmunoassay in acute and chronic HBV infections in Tunisia. Prog Clin Biol Res.1987;234:441-2.

66. Bassily S, Hyams KC, el Ghorab NM, Ansari AA, Fanous AS. Acute sporadic hepatitis in adults living in Cairo, Egypt. Am J Trop Med Hyg.1986;35(5):1040-4.

67. Ghabrah TM, Strickland GT, Tsarev S, Yarbough P, Farci P, Engle R, et al. Acute viral hepatitis in Saudi Arabia: Seroepidemiological analysis, risk factors, clinical manifestations, and evidence for a sixth hepatitis agent. Clin Infect Dis.1995;21(3):621-7.

68. Glynn MJ, Rashid A, Antao AJO. Imported epidemic non-A, non-B hepatitis in Qatar. J Med Virol.1985;17(4):371-5.

69. Gunaid AA, Nasher TM, el-Guneid AM, Hill M, Dayton R, Pal A, et al. Acute sporadic hepatitis in the Republic of Yemen. J Med $\mathrm{Vi}$ rol.1997;51(1):64-6.

70. Haider Z, Khan AA, Rehman K, Janjua MI, Iqbal J, Chishti MA, et al. Sero-diagnosis for viral hepatitis in 93 patients admitted with acute hepatitis in three different teaching hospitals in Lahore. $J$ PakMed Assoc.1994;44(8):182-4

71. Marcus S, Al-Moslih M, Al-Tawil NG, Kassir ZA. Virological and immunological studies in patients with acute viral hepatitis. Scand JImmunol.1993;37(2):265-70.

72. Meky FA, Stoszek SK, Abdel-Hamid M, Selim S, Abdel-Wahab A Mikhail N, et al. Active surveillance for acute viral hepatitis in rural villages in the Nile Delta. Clin Infect Dis.2006;42(5):628-33.

73. Rassam SW, Goudeau AM, Dubois F, Al-Khoury BN, Muhyee AlDeen JA, Sadik AM. Acute viral hepatitis: An aetiological study of 253 patients. J Gastroenterol Hepatol.1989;4(2):151-4.

74. Abdel-Fattah S, el-Kholy MS, Abdel-Fattah SM, el-Shimi S, elRasad MM, Mikhail TH, et al. Delta virus and hepatitis B surface antigen in chronic liver diseases. J Egypt Public Health Assoc.1991;66(3-4):427-39.

75. Bahakim H, Ramia S, Kurbaan K. Combined immunoprophylaxis in the prevention of perinatal transmission of hepatitis B and hepatitis D virus infections in Saudi children. Ann Trop Paediatr.1990;10(2):139-43.

76. Morcos MM, Mikhail TH, Hanna WM, Abdel-Fattah S, el-Rasad $\mathrm{MM}$, Wassef EL. The prevalence of delta virus infection in chronic liver disease in Egyptian children in comparison with some other countries. Panminerva Med.2000;42(2):97-100.

77. al Adnani MS. Hepatitis B core and surface antigens and delta agent in chronic liver disease in Kuwait. Histol Histopathol.1988;3(1):57-62.

78. Al-Moslih MI, Al-Huraibi MA. Prevalence of hepatitis C virus among patients with liver disease in the Republic of Yemen. East Mediterr Health J.2001;7(4-5):771-8.

79. Arya SC, Ashraf SJ, Parande CM, Tobeiqi MS, Ageel AR. Hepatitis B and delta markers in primary hepatocellular carcinoma patients in the Gizan area of Saudi Arabia. APMIS Suppl.1988;3:30-4.

80. Bashardust n. seroprevalance of HDV in high risk group. Med J Shahid Sadughi Yazd.1999;3:51.

81. Farci P, Burroughs AK, Thomas HC, Shamma'a M. Delta hepatitis in Lebanon. Prevalence studies and a report on six siblings with chronic delta-positive active hepatitis.J Hepatol.1987;4(2):224-8.

82. Nordenfelt E, Hansson BG, Al-Nakib B. Frequency of delta agent infections in Kuwait. J Infect Dis.1983;148(4):768.

83. Ramia S, el-Hazmi MA, Vivian PA, Waller DK, Mushahwar IK, Frosner GG. Delta agent infection in Riyadh, Saudi Arabia. Trans $R$ Soc Trop Med Hyg.1987;81(2):317-8.

84. Vosoughinia H, Esmailzadeh A, Mokhtarifard A, Sima HR, Saadatnia H, Khosravi A. Seroepidemiology and co infetion of hepatitis $D$ virus infection in the north-east of Iran. Med J Mashhad Unive Med Sci.2010;53(2):69-72.

85. Zaidi G, Idrees M, Malik FA, Amin I, Shahid M, Younas S, et al. Prevalence of Hepatitis Delta Virus infection among Hepatitis B Virus surface antigen positive patients circulating in the largest province of Pakistan. Virol J.2010;7(1):283.

86. Zuberi BF, Quraishy MS, Afsar S, Kazi LA, Memon AR, Qadeer R, et al. Frequency and comparative analysis of hapatitis D in petients seeking treatment for hepatitis B. J Coll Physicians Surg Pak.2006;16(9):581-4.

87. Jacobson IM, Dienstag JL, Werner BaG, Brettler DB, Levine PH, Mushahwar IK. Epidemiology and clinical impact of hepatitis D virus (delta) infection. Hepatology.1985;5(2):188-91.

88. Abbatte EA, Fox E, Salah S, Constantine NT, Wassef HH. Ethnic differences in the prevalence of hepatitis delta agent in Djibouti. Trans R Soc Trop Med Hyg.1989;83(1):107-8.

89. Angelico M, Renganathan E, Gandin C, Fathy M, Profili MC, Refai $\mathrm{W}$, et al. Chronic liver disease in the Alexandria governorate, Egypt: contribution of schistosomiasis and hepatitis virus infections. J Hepatol.1997;26(2):236-43.

90. Darwish MA, Shaker M, Raslan O, Raouf TA. Hepatitis B \& D viral infections among schistosomal patients in Egypt. J Egypt Public Health Assoc.1992;67(5-6):549-63.

91. Darwish MA, Shaker M, Raslan OS, Abdel-Raouf T. Delta virus infection in Egypt. J Egypt Public Health Assoc.1992;67(1-2):147-61.

92. el Zayadi A, Ponzetto A, Selim O, Forzani B, Lavarini C, Rizzetto M. Prevalence of delta antibodies among urban HBsAg-positive chronic liver disease patients in Egypt. Hepatogastroenterology.1988;35(6):313-5.

93. Youssef A, Yano Y, Utsumi T, abd El-alah EM, abd El-Hameed Ael E, Serwah Ael H, et al. Molecular epidemiological study of hepatitis viruses in Ismailia, Egypt. Intervirology.2009;52(3):123-31.

94. Zaki S, Khatwa MA, Mikhail H. Prevalence of infection with delta virus in patients positive for hepatitis B surface antigen. Int J Infect Dis.2010;14:S55

95. Alavian SM, Asari SH, Manzoori-Joybari H, Moghani Lankarani M Doroudi T, HajiBeigi B, et al. [Frequency and risk factors of hepatitis D virus in hepatitis B patients]. Govaresh.2004;3(9):169-75.

96. Alizadeh AH, Ranjbar M, Tehrani AS, Keramat F, Mamani M, Rezazadeh M, et al. Seroprevalence of hepatitis D virus and its risk factors in the west of Iran. J Microbiol Immunol Infect.2010;43(6):519-23.

97. Amini S, Mahmoodi MF, Andalibi S, Solati A. Seroepidemiology of hepatitis B, Delta and HIV infections in Hamadan province of Iran.J. Trop. Med. Hyg.1993;96:277-87.

98. Amini S, Taghinia A, Khanbaba F, Talebian A. Prevalence of Delta agent super-infection and co-infection among HBsAg-positive patients referring to reference IBTO Lab [In Persian]. Hakim Res 
J.2007;9(4):7-11.

99. Ataei B, Yazdani MR, Kalantari H, Yaran M, Nokhodian Z, Javadi AA, et al. Delta hepatitis infection in patients with chronic hepatitis B infection in Isfahan, Iran. Clin Microbiol Infect.144:41.6.

100. Doosti A, Amini-Bavil-Olyaee S, Tajbakhsh E, Adeli A, Mahboudi F. Prevalence of viral hepatitis and molecular analysis of HBV among voluntary blood donors in west Iran. New Microbiol.2009;32(2):193-8.

101. Habibi F, Mokhtari H, Gazerani M, Roshani Zaferanloo N. The Frequency of Hepatitis Delta in Hepatitis B surfuce antigen positive patients. Med Sci J Islamic Azad Univ Mashhad Branch.2000;5(3):61-7.

102. Hajiani E, Hashemi S, Masjedizadeh A. Seroepidemiology of Hepatitis B Virus Infection in Khuzestan Province, Southwest of Iran. Hepat Mon.2009;9(1):34-8.

103. Hassanjani Roshan MR, Beigi AA, Soleimani MJ. [Prevalence of anti-HDV in chronic carrier of $\mathrm{HBV}$ in Babol]. Babol Med J.2004;6(21):50-4.

104. Jedary Seifi S, Sabouri Ghannad M. A Study of HDV in HBsAg Positive Patients in Tabriz, Northwestern Iran. Hepat Mon.2010;10(2):110-5.

105. Karimi A, Amini S, Amirkhani A. [Investigation and Comparison of hepatitis D prevalence in dialysis patients and the donors of HBsAg carrier]. Teb va Tazkieh.2000;36:30-5.

106. Makvandi M, Samrbafzadeh AR, Malekan E. Determination of HBV, HCV and HDV markers among the cirrhotic patients. J Gastroenterol Hepatol.2004;19(Suppl):A760.

107. Malekzadeh R, Borhanmanesh F. Prevalence of HDV in asymptomatic healthy carrier of HBV in Iran. Iran JMed Sci.1989;14(2):338.

108. Rezvan H, Taroyan S, Forouzandeh B, Fadaiee S, Azordegan F. A study on delta virus infection and its clinical impact in Iran. Infection.1990;18(1):26-28.

109. Roshandel G, Semnani SH, Abdolahi N, Keshtkar A, Besharat S, Joshaghni $\mathrm{H}$, et al. Prevalence of Hepatitis D Virus Infection in HBsAg Positive Subjects in Iran. PakJ Biol Sci.2007;10(10):1751-1754.

110. Somi MH, Farhang S, Miri SM, Pouri AA, Mjidi G, Alavian SM. The frequency of hepatitis D virus in patients with hepatitis B in Iran: an increasing rate? Trop Doct.2009;39(3):154-6.

111. Taghavi SA, Sedighi SH, Mehrabani D, Khademolhosseini F. Hepatitis D in chronic active hepatitis B: prevalence, liver enzymes and histopathology- an epidemiological study in Shiraz, southern Iran, 2003-2004. Hepat Mon.2008;4(8):248-51.

112. Taghvaei T, Khanlarpor M, Mahdavi Mohammad R, Tirgar Fakher $\mathrm{H}$, Maleki I, Khalilian AR. Prevalence of positive Hepatitis Delta Virus in patients with positive Hepatitis B surface Antigen and its correlative factors in Sari. JMazandaran Univ Med Sci.2008.

113. Zahedi M, Darvish-Moghaddam S, Zareei H. Clinical Impact and Frequency of Hepatitis D Virus Infection in HBsAg Positive Patients in a Southern Province of Iran (Kerman). Iran J Virol.2010;3(2):1-6.

114. Toukan AU, Abu-El-Rub OA, Abu-Laban SA, Tarawneh MS, Kamal MF, Hadler SC, et al. The epidemiology and clinical outcome of hepatitis D virus (Delta) infection in Jordan. Hepatology.1987;7(6):1340-5.

115. Alkandari S, Mahbut S, Nordenfelt E, al-Nakib B, al-Nakib W. Fulminant viral hepatitis in Kuwait. Ann Trop Med Parasitol.1988;82(6):555-9.

116. Ramia S, El-Zaatari M, Sharara AI, Ramlawi F, Farhat B. Current prevalence of hepatitis delta virus (HDV) infection and the range of HDV genotypes in Lebanon. Epidemiol Infect.2007;135(6):959-62.

117. Rioche M, Himmich H, Hansson BG, Nordenfelt E. [Low occurrence of delta agent infections in Morocco]. Bull Soc Pathol Exot Filiales.1987;80(5):741-4.

118. Aghanashinikar PN, al-Dhahry SH, al-Marhuby HA, Buhl MR, Daar AS, Al-Hasani MK. Prevalence of hepatitis B, hepatitis delta, and human immunodeficiency virus infections in Omani patients with renal diseases. Transplant Proc.1992;24(5):1913-4

119. Baig S, Siddiqui AA, Ahmed WU, Qureshi H, Arif A. Frequency of hepatitis $\mathrm{C}$ and D super infection in patients with hepa- titis B related complex liver disorders. J Coll Physicians Surg Pak.2009;19(11):699-703.

120. Das K, Ali H, Mahmood T, Munir SM, Ahmed T, Farooq MU. Comparative analysis of disease activity in patients of chronic hepatitis B virus, with and without superinfection with hepatitis D virus; an experience at tertiary care centre. JAyub Med Coll Abbottabad.2008;20(2):39-42.

121. Qureshi H, Zuberi SJ, Lodi TZ, Alam E. Clinical features, course, viral markers and follow-up in young versus adult nonalcoholic cirrhotics--a retrospective study. Digestion.1989;42(2):110-5.

122. Saeed Ur R, Hafiz A. Seroprevalence of HDV in hemodialysis and drug addicts in Karachi.JColl Physicians Surg Pak.2000;10(12):470-

123. Seetlani NK, Abbas Z, Raza S, Yakoob J, Jafris W. Prevalence of hepatitis D in HBsAg positive patients visiting liver clinics. J Pak Med Assoc.2009;59(7):434-7.

124. Ur Rahman S, Hafiz A. Study of hepatitis D in high risk population of hepatitis B. JColl Physicians Surg Pak.2000;10(1):29-32.

125. Aceti A, Mohamed OM, Paparo BS, Mohamud OM, Quaranta G, Maalin KA, et al. High prevalence of anti-hepatitis delta virus antibody in chronic liver disease in Somalia. Trans $R$ Soc Trop Med Hyg.1991;85(4):541-2.

126. Aceti A, Paparo BS, Celestino D, Pennica A, Caferro M, Grilli A, et al. Sero-epidemiology of hepatitis delta virus infection in Somalia. Trans R Soc Trop Med Hyg.1989;83(3):399-400.

127. Bile K, Aden C, Norder H, Magnius L, Lindberg G, Nilsson L. Important role of hepatitis $C$ virus infection as a cause of chronic liver disease in Somalia. Scand J Infect Dis.1993;25(5):559-64.

128. Bile KM, Abdirahman M, Aden C, Norder H, Magnius L, Lindberg $\mathrm{G}$, et al. Minor role of hepatitis B virus in the causation of chronic liver disease in Somalia indicated by a case-control study. Trans $R$ Soc Trop Med Hyg.1991;85(1):104-8.

129. al Nasser MN, al Mugeiren MA, Assuhaimi SA, Obineche E, Onwabalili J, Ramia S. Seropositivity to hepatitis C virus in Saudi haemodialysis patients. Vox Sang.1992;62(2):94-7.

130. Al Traif I, Ali A, Dafalla M, Al Tamimi W, Qassem L. Prevalence of hepatitis delta antibody among HBsAg carriers in Saudi Arabia. Ann Saudi Med.2004;24(5):343-4.

131. Alzahrani AJ, Dela Cruz DM, Obeid OE, Bukhari HA, Al-Qahtani AA, Al-Ahdal MN. Molecular detection of hepatitis B, hepatitis $\mathrm{C}$, and torque teno viruses in drug users in Saudi Arabia. J Med Virol.2009;81(8):1343-7.

132. Ashraf SJ, Arya SC, Parande CM. Viral hepatitis markers in patients on haemodialysis in a hyperendemic area. $J$ Med $\mathrm{Vi}$ rol.1986;19(1):41-6.

133. Ashraf SJ, Arya SC, Parande CM, Sahay R, Ageel AR. Anti-delta antibody in primary hepatocellular carcinoma patients in the Gizan area of Saudi Arabia. Infection.1986;14(5):250-1.

134. Fathalla SE, Abdulazziz FM, Sabri HS, Abdulhameed O. Seroepidemiological prevalence of hepatitis delta virus in Eastern Saudi Arabia. Annals of Saudi Medicine.1994;14(6):503-6.

135. Njoh J, Zimmo S. Prevalence of antibody to hepatitis D virus among HBsAg-positive drug-dependent patients in Jeddah, Saudi Arabia. East Afr Med J.1998;75(6):327-8.

136. Ramia $S$, Bahakim $H$. Perinatal transmission of hepatitis B virus-associated hepatitis D virus. Ann Inst Pasteur Virol.1988;139(3):285-90.

137. Sheth KV, Schifano J, Carr A. Anti-delta-virus antibody in sera positive for hepatitis B surface antigen in male Saudi blood donors. Ann Saudi Med.1989;9(5):463-5.

138. Djebbi A, Rebai WK, Bahri O, Hogga N, Sadraoui A, Triki H. [Serological markers, viral RNA and genotype of hepatitis delta virus in HBs antigen positive Tunisian patients]. Pathol Biol (Paris).2009;57(7-8):518-23.

139. Jenhani F, Ayed K, Gorgi Y, Zoulim F, Pichoud C, Trepo C. Delta infection in chronic HBs Ag carriers in Tunisia: high prevalence in chronic asymptomatic HBs Ag carriers and in $\mathrm{HBs} \mathrm{Ag}$ positive cirrhosis. Ann Trop Med Parasitol.1990;84(4):349-53.

140. Skouri H, Gandouz R, Hammami N, Kraiem I, El Omri H. [HBeAg/ Anti-HBe status, anti-HD and ALT levels in blood donors found to be chronic AgHBs carriers]. Med Mal Infect.2004;34(4):181-2. 
141. Triki H, Said N, Ben Salah A, Arrouji A, Ben Ahmed F, Bouguerra A, et al. Seroepidemiology of hepatitis B, C and delta viruses in Tunisia. Trans R Soc Trop Med Hyg.1997;91(1):11-4

142. el Guneid AM, Gunaid AA, O'Neill AM, Zureikat NI, Coleman JC, Murray-Lyon IM. Prevalence of hepatitis B, C, and D virus markers in Yemeni patients with chronic liver disease. J Med Virol.1993;40(4):330-3.

143. Scott DA, Burans JP, al-Ouzeib HD, Arunkumar BK, al-Fadeel M, Nigad YR, et al. A seroepidemiological survey of viral hepatitis in the Yemen Arab Republic. Trans RSoc Trop Med Hyg.1990;84(2):28891.

144. Al-Arabi MA, Hyams KC, Mahgoub M. Non-A, non-B hepatitis in Omdurman, Sudan. J Med Virol.1987;21(3):217-222.

145. Woodruff PW, Morrill JC, Burans JP, Hyams KC, Woody JN. A study of viral and rickettsial exposure and causes of fever in Juba, southern Sudan. Trans R Soc Trop Med Hyg.1988;82(5):761-6.

146. Pascarella S, Negro F. Hepatitis D virus: an update. Liver Int.2011;31(1):7-21.

147. Fonseca JCF, Simonetti SRR, Schatzmayr HG, Castejón MJ, Cesário ALO, Simonetti JP. Prevalence of infection with hepatitis delta virus (HDV) among carriers of hepatitis B surface antigen in Amazonas State, Brazil. Trans R Soc Trop Med Hyg.1988;82(3):469-471.

148. Hadler SC, Alcala de Monzon M, Rivero D, Perez M, Bracho A, Fields $\mathrm{H}$. Epidemiology and long-term consequences of hepatitis delta virus infection in the Yucpa Indians of Venezuela. Am J Epidemiol.1992;136(12):1507-16.

149. Degertekin H, Yalcin K, Yakut M, Yurdaydin C. Seropositivity for delta hepatitis in patients with chronic hepatitis B and liver cirrhosis in Turkey: a meta-analysis. Liver Int.2008;28(4):494-8.

150. Tsatsralt-Od B, Takahashi M, Nishizawa T, Endo K, Inoue J, Okamoto $\mathrm{H}$. High prevalence of dual or triple infection of hepatitis $\mathrm{B}, \mathrm{C}$, and delta viruses among patients with chronic liver disease in Mongolia. J Med Virol.2005;77(4):491-9.

151. Fattovich G, Giustina G, Christensen E, Pantalena M, Zagni I, Realdi $G$, et al. Influence of hepatitis delta virus infection on morbidity and mortality in compensated cirrhosis type B. The European Concerted Action on Viral Hepatitis (Eurohep) Gut.2000;46(3):420-6.

152. Saracco G, Rosina F, Brunetto MR, Amoroso P, Caredda F, Farci P, et al. Rapidly progressive HBsAg-positive hepatitis in Italy: The role of hepatitis delta virus infection.J Hepatol.1987;5(3):274-281.

153. Chang SY, Yang CL, Ko WS, Liu WC, Lin CY, Wu CH, et al. Molecular epidemiology of hepatitis D virus infection among injecting drug users with and without human immunodeficiency virus infection in Taiwan. JClin Microbiol.2011;49(3):1083-9.

154. Nwokediuko SC, Ijeoma U. Seroprevalence of antibody to HDV in Nigerians with hepatitis B virus-related liver diseases. Niger JClin Pract.2009;12(4):439-42.

155. Rapicetta M, Hailu K, Ponzetto A, Hele C, Morace G, Bekura D, et al. Delta hepatitis virus infection in ethiopia. Eur J Epidemiol.1988;4(2):185-188.

156. Foupouapouognigni Y, Noah DN, Sartre MT, Njouom R. High prevalence and predominance of hepatitis delta virus genotype 1 infection in Cameroon. J Clin Microbiol.2011;49(3):1162-4

157. Kim HS, Kim SJ, Park HW, Shin WG, Kim KH, Lee JH, et al. Prevalence and clinical significance of hepatitis D virus coinfection in patients with chronic hepatitis B in Korea. J Med Virol.2011;83(7):1172-7.

158. Chakraborty P, Kailash U, Jain A, Goyal R, Gupta RK, Das BC, et al. Seroprevalence of hepatitis D virus in patients with hepatitis $\mathrm{B}$ virus-related liver diseases. Indian J Med Res.2005;122(3):254-7.

159. Chen X, Xuan M, Yin Y. [Study of HDV infection in Shandong province]. Zhonghua Liu Xing Bing Xue Za Zhi.1998;19(3):138-40. 